\title{
Examining the Barriers to Reporting Sexual Harassment in Universities
}

\author{
Agnes Namaganda ${ }^{1^{*}}$, Dr. Sarah Ssali ${ }^{2}$, Dr. Ronald Bisaso ${ }^{3}$ \\ ${ }^{I}$ Post Graduate Student: East African School of Higher Education Studies and Development, College of \\ Education and External Studies, Makerere University, Uganda \\ ${ }^{2}$ Associate Professor, School of Women and Gender Studies, College of Humanities and Social Sciences, \\ Makerere University, Uganda \\ ${ }^{3}$ Associate Professor, East African School of Higher Education Studies and Development, College of Education \\ and External Studies, Makerere University, Uganda
}

\begin{abstract}
*Corresponding Author: Agnes Namaganda, Post Graduate Student: East African School of Higher Education Studies and Development, College of Education and External Studies, Makerere University, Uganda.Email: aryaggie@yahoo.co.uk
\end{abstract}

\begin{abstract}
Universities have responded to sexual harassment by putting in place formalized reporting processes through which victims can seek redress. Despite these processes, victims seldom invoke the grievance handling mechanisms that are enshrined in university sexual harassment policies. This study therefore sought to investigate why the vice is grossly under reported. Given the asymmetrical relationship between students and faculty as well as the gendered position of female students, this study specifically focused on why female undergraduate students seldom reported faculty perpetrated sexual harassment.
\end{abstract}

The study was carried out at a large public university in East Africa, was purely qualitative and involved 42 participants who included students, members of faculty and university administrators. The data was analyzed thematically.

Findings: The findings indicated that institutional and social cultural barriers coupled with power asymmetries were the major barriers to the reporting of sexual harassment amongst female university students.

These findings are beneficial to universities especially as they seek to revise their existing sexual harassment policies. Any meaningful attempt to encourage female students to report sexual harassment ought to minimize the negative consequences that may accrue from reporting the vice. This may help victims to build trust in the grievance handling mechanisms thus encouraging them to report the vice.

Keywords: Universities, Non-reporting, Sexual harassment, Power

\section{INTRODUCTION}

University campuses provide convenient environments for members of faculty and students to interact. This in itself provides opportunities for behavioral deviance to occur thus resulting into sexual harassment. Despite sexual harassment being wide spread in academia [1], and universities putting in place anti sexual harassment policies complete with grievance handling mechanisms to combat it $[2,3,4]$, the vice remains grossly underreported [5,6]. Given their subject position, all university students can potentially be victims of sexual harassment, however female students are particularly at risk because of their gendered subordinate position [7, 8]. The sexual harassment of female students has therefore been recognized as a cause of great concern $[9,10]$.

Policy makers appear to have definite views about how victims of sexual harassment should react to the vice; by reporting it [11].However the promises made in sexual harassment policies have not done enough to encourage victims of the vice to step forward [12]. Only a few victims invoke the grievance handling mechanisms that are enshrined in university anti sexual harassment policies $[13,3]$ and yet sexual harassment in academia cannot be tackled without the cooperation of the victims [14]. 


\section{LITERATURE REVIEW}

The under and non-reporting of sexual harassment diminishes the ability of anti-sexual harassment policies to fight the vice while also giving the impression that the problem is nonexistent [15]. The risks of repeated harassment have been noted to be higher when it is not reported [1]). Non-reporting has been attributed to faulty grievance handling mechanisms that are enshrined in university anti sexual harassment policies [3]. These discourage victims from reporting as they are wrought with an inherent conflict whereby the university which is obligated to provide a safe learning environment for its students also has an interest in the complaints as it tries to protect its image and to insulate itself from legal responsibility for the wrongs done by its employees [16].

In studies done prior on why victims of sexual harassment may not report, it was established that the reasons most frequently given were a threat of retaliation, perceived inaction on the part of complaint handlers and the shame suffered by victims of sexual harassment [17].Other studies established that some women did not report sexual harassment because they considered it to be trivial. However, they were more willing to report forms of harassment that they perceived to be severe $[18,19]$. The fear of being blamed also stops victims from reporting their experiences [20,21]. This has been attributed to cultural factors as well as sexual and gender stereotypes which privilege men's aggressive sexual behavior while blaming women for men's sexual wrongs [11].It has also been suggested that women who experience the reoccurrence of sexual harassment are less likely to report it because the incidences lower their self-esteem which in turn diminishes their ability to respond to sexual harassment [22]. However, available literature is devoid of studies that have examined the barriers to reporting sexual harassment in universities in East Africa. Also in contrast to other studies that dealt with women in the public sphere, this study specifically focused on undergraduate female students given their gender and subject position within the university hierarchy. Universities worldwide are known for their asymmetries in power especially between students and faculty [23].The relationship between the two is a dependent and asymmetrical one [23, 24].

The study is significant as an examination of the barriers to reporting may provide universities the much needed answers on how to encourage victims of sexual harassment to step forward. By paying attention to the reasons for not filing complaints, organizations may look at their complaint procedures to determine if they are sufficient enough to encourage victims to come forward [25].

\section{CONTEXT OF THE STUDY}

This section presents an overview of the process and structure through which victims of sexual harassment at the time this study was carried out could report sexual harassment. It is intended to help the reader better understand the findings of the study.

This study was carried out at a large public university in East Africa. At the time of collecting data for this study, the university had a sexual harassment policy that had been formulated in 2006. The university had decentralized the handling of sexual harassment complaints to academic units with each unit required to compose a unit anti sexual harassment committee in charge of handling complaints that arose within it. The committees were by default headed by the heads of academic units. They comprised of a pool of ten persons of whom 50\% had to be women. When a unit sexual harassment committee failed to handle a complaint, they were obligated to pass it on to a higher committee. The timeframe within which a complaint could be addressed was put at three months with the exception of certain special circumstances.

\section{Methodology}

This study was purely qualitative and was guided by the case study design. Participants in this study included students, members of faculty as well as university administrators. In total, 42 participants took part in the study. Data was collected through interviews over a period of 6 months. Participants were asked questions about why female students seldom reported sexual harassment. Female students who identified themselves as victims and had not reported were asked why they had not reported. Thematic analysis was used to identify patterns in the data. The analysis of the data consisted of coding, identification of categories, subthemes and the identification of themes.

\section{Presentation OF Findings}

Analysis of the data yielded three themes: institutional barriers, social barriers as well as financial inadequacy.

5.1. Institutional Barriers: The findings of this study suggested that some of the barriers to reporting sexual harassment were related to the investigative practices that were insensitive to victims and 
the power differentials that are inherent in universities. Institutional barriers manifested themselves in the inaction of complaint handlers, bias in the handling of sexual harassment complaints and the insistence on clear and convincing evidence. Participants in this study noted that that they refrained from reporting sexual harassment because they did not have the evidence to back up their claims and the perception that even when one reported, they could be met with inaction. A female student when asked why she had not reported her sexual harassment experience noted;

\section{I did not have evidence that he had harassed me but I have also heard that even when you report, they do not do anything so why bother?}

The participant above illuminates how a lack of evidence and perceptions that the reporting of sexual harassment will be met with indifference encumbers victims from reporting complaints. These sentiments were echoed by two female students who alluded to how a lack of clear evidence may hamper victims of sexual harassment from reporting. One female student opined;

I would not report. How do I start to explain? Will they even believe me? The lecturer will probably say that he has never seen me in the office. Maybe if I have good test paper marks and then I argue that basing on this, I do not have a reason to fail. Even if I have a recording, he can deny because he could say that is not my voice. So I would fear to report because the recording may not back me up. What if I am reporting to a friend of the harasser who actually might turn tables against me.

The participant above alluded to various reasons that could stop her from reporting sexual harassment. She was fearful that her account of what happened could not be believed by the complaint handlers and that the accused person could deny that it ever happened. The participant also expressed doubt in the ability of complaint handlers to handle cases fairly. It ought to be noted that at the time data for this study was collected, the handling of sexual harassment complaints had been decentralized to units with the unit heads chairing the unit sexual harassment committees. The participant's views point to a lack of trust in the grievance handling mechanism. Owing to the professional closeness of members of sexual harassment committees and faculty accused of perpetrating sexual harassment, it is highly likely that the decentralized handling of sexual harassment complaints was ineffective. Another female student noted how a lack of evidence and the perceived inaction of complaint handlers acted as stumbling blocks for those who might want to seek justice:

Students know that even when they report, nothing will happen to the harasser. They tell you to start with the Head of Department and he asks you for evidence and sometimes this is not easy because maybe the lecturer touched you and you have no evidence. The Head of Department tells you to go back and ensure that you get evidence. That bureaucracy, students get fed up.

The participant illuminates how a lack of clear evidence stops victims from reporting complaints. She also points to how victims of sexual harassment may be re-victimised in the name of collecting sufficient evidence to back up their claims.

The findings also indicated that the threat of retaliation from alleged perpetrators potentially prevented victims of sexual harassment from reporting complaints. A female student who at the time of collecting data for this study was experiencing sexual harassment noted;

He (perpetrator) has told me that even if I reported him, no one could believe me. He also told me that he could make me fail so when I think about all those things, I am better off not reporting him. Besides, I have heard that he does those things to other students and that he has done it over the years but nothing is done to him.

The participant prior expressed her fear for what the harasser could do given that that he had professional responsibility over her. She was clearly afraid of the possibility of academic failure and like participants prior, she alluded to the notion that perpetrators are seldom punished for their behavior. What she said concurred with another female student who noted that it was difficult for victims to report someone who had the power to determine their grades and thus students consciously chose not to report faculty who sexually harassed them.

You see, sometimes the girls want to report but you have to think twice before you do. Sometimes this lecturer is teaching you so you do not want them to fail you and you need the marks. But students also know that even when you report, little or nothing is done. I am yet to hear of a lecturer who lost their job because of sexually harassing students. If you find that your mark is missing on the notice board, you have to go to the respective lecturer, how do you then report such a person? 
The threat of retaliation not only emanated from the perpetrator but also from the professional network to which the perpetrator belonged. Participantsindicated that reporting a faculty member for sexual harassment could attract the ire of other members of faculty to academically fail the victim. A female student noted thus;

Sometimes victims are scared, they feel like if they report this person, they are going to face consequences. He can fail you and you can also fail any paper because his (perpetrator's) friends can fail you too.

While another opined

If I report and other lecturers get to know, some will definitely make me fail their papers because they know that you reported a colleague.

What the participants above said about the threat of retaliation was corroborated by faculty members who noted that a student who reported a faculty member for sexual harassment could most likely suffer negative consequences. One male member of faculty noted;

It takes a lot of courage to report. If a student goes to the Head of Department and nothing is done, the student's life and studies are now in danger. The problem has not been addressed andthe victim is supposed to go back to the same class and be taught by the same lecturer that one has issues with. If you see a lecturer being punished and it is put on notice boards, the others would fear. When results are released, they should be cross checked especially in instances where such cases are involved. That follow up is not usually done. At the end of the day when exams are done, he marks you and you end up with low marks. It becomes hard for someone to explain. Such students have to study extra hard so as to pass. You can imagine, you go through one year of harassment, you get a retake (below pass mark) and you are sent back to the harasser. If you report me for sexual harassment, if you are not good enough, you will still fail the paper. The students are always on the losing side.

A female faculty member also noted how the threat of retaliation prevented students from reporting faculty for sexual harassment as thus;

Of course they (victims) are worried about their future, they are afraid of what the lecturer can do. Most of the time, perpetrators deny so the girls end up sitting back.

What the two members of faculty above say lends credence to what the female students said about the threat of retaliation. Retaliatory behavior is largely tied to the asymmetrical and dependent relationship between students and faculty and is thus closely tied to where power lies in academia. Members of faculty by virtue of the positions they hold have enormous power over students. This power can be abused by harassers to punish students who report them for sexual harassment. The threat of retaliation explains why female students may be more willing to file complaints after they have finished their courses. Indeed, the findings indicated so as shared by two female faculty members who held administrative positions in their academic units. One of them opined;

You see the students do not want to talk, people who talk do that after they have gone through it. There was a student who finished her course and then she came and told me, "Why don't you call up that Dr. (name withheld)?" I asked why? The student said, that man when he supervised us on school practice, he was demanding for sex. I asked the student, why didn't you say so when you were still a student? She said no way.

While another noted;

You see most of these things, we hear from students themselves. The students say they will not bring up these issues and if they must bring out these issues, it is when they have completed their courses. There are some who have come here crying and they say it is ABC and I say why didn't you report when it happened? And they say that you cannot report when you are in second year and the same lecturer is going to teach you in third year so they prefer not to report.

The willingness of students to report sexual harassment after the completion of their studies further confirms the threat of retaliation. When students complete their studies, they are no longer bound by the threat of retaliation and are therefore more willing to talk. Owing to the asymmetries in power between faculty and students, chances of retaliation are high for a student who reports a case of sexual harassment against a member of faculty where a professional relationship exists. The decision not to report sexual harassment may be a practical and carefully calculated decision on the part of the students. 
The findings further suggested that the inaction of complaint handlers coupled with the red tape surrounding the handling of sexual harassment complaints prevented victims from coming forward One female student responding to why victims did not report sexual harassment noted;

The policy exists but you have to move from one office to another, by the time you reach the last one, you are exhausted. Even the people in these offices frustrate us a lot. To make it difficult, you find that the perpetrator is a friend to the person that you are reporting to, in that scenario, what do you do? They keep referring you to come again and again until you are frustrated and cannot do it anymore.

The participant above illuminates how the bureaucracy surrounding the handling of sexual harassment may discourage victims from reporting complaints. The participant calls into doubt the ability of complaint handlers to handle complaints fairly. At the time of collecting data for this study, the handling of sexual harassment complaints had been decentralized to the various heads of academic units. Complaint handlers were themselves members of faculty and were therefore socially and professionally closer to other members of faculty some of whom could have been accused of perpetrating sexual harassment. Given this background, they may not have been able to neutrally handle complaints.

Another participant noted that since there were no past successes in dealing with the vice, victims were reluctant to come forward knowing that no action could be taken against the perpetrators;

The challenge is that no one has been brought to book successfully. So they feel that the harassers will go scoot free and the harassers also tell them; "What will they do to me, you are not my first victim?"It is important to remember that in the African society, issues of sexuality are hardly talked about.

The perceived inaction on the part of complaint handlers may have led to a loss of trust in the grievance handling mechanism. However the participant also alludes to how the veiled nature of sexuality may prevent victims from coming forward. Victims may thus not report sexual harassment because of the belief that matters of sexuality should be kept private.

The findings also indicated that there had been a poor dissemination of the grievance handling mechanism. Despite the university having a well set up structure within which complaints could be handled, some participants noted that they did not know where to report sexual harassment. A female student who had experienced sexual harassment from a male member of faculty explained that she did not report the harassment partly because she did not know where to report it;

First, I did not know where to report a case like that but also he was my lecturer and maybe he was going to teach me the following semester and had also not released my marks, how do you report someone like that?

The participant above was barely informed about the reporting structure and like participants prior, she too lays claim to how the power of perpetrators can encumber victims from stepping forward.

Another female student opined;

I do not know where I am supposed to report. I do not know what I can do and I do not know if I am safe. My fellow students will look down upon me.

The participant raises pertinent issues that may hamper victims of sexual harassment from reporting their experiences. She did not know where to report the harassment but also made reference to the shame that victims of sexual abuse face. This too can stop victims from coming forward. What the students said was corroborated by a female member of faculty who noted that;

Students are not informed because even in my case, I only got to know of the policy through a gender activist in my unit who raised these issues. Now just imagine a department without someone who is interested in gender issues. I am informed because I teach a course in workers education and there is a section on harassment at work, so I know that people should not be harassed at work and that helps my knowledge. But I want to tell you that the students are not informed, students seldom turn up for orientation trainings so it then takes a teacher with an interest there to let the students know about what sexual harassment is.

What the participant says points to a poor dissemination of the grievance handling mechanism. The implication of this is that victims may not report complaints because they do not know where to report them. 
The findings also suggested that victims who get a benefit in return for being sexually harassed may be reluctant to report the vice. It was particularly noted that academic benefits accrued from quid pro quo harassment may stifle reporting. Participants in this study attested to this as they noted that victims who were sexually harassed and in turn given a better grade by their instructors seldom reported the harassment. When asked why victims were reluctant to step forward, one female student noted;

Some lecturers give students marks in exchange for sleeping with them, I do not think that such a student will report, they just keep quite. I hear about those complaints from my classmates. They say so and so never hands in course work in time, never attends lectures but she has very good grades and you wonder how they got them but of course you cannot do anything.

What the participant above said was corroborated by an administrator at an academic unit who noted that when there has been an exchange between the perpetrator and the victim, the incident might not be viewed as sexual harassment and will most likely not be reported. She noted;

You hear the students complaining that so and so got marks because of ABCD. I have even heard a suspicion, it is not sexual harassment when they consent. You know it's a transaction and somebody got their first class. I have heard but you know some of them, you know you meet the students later and then you cannot call it sexual harassment because it was consent. The cases we get to know are because the student has not agreed, that is when we come to hear of it as harassment. When they have agreed, you hear the stories later.

The administrator above points to the complexities around reporting sexual harassment. Despite what the university's anti sexual harassment policy says about quid pro quo harassment, it might be hard to root out if victims comply with the demands of the perpetrators and receive better grades in return. These findings are a pointer to how the power differentials that are inherent in academia stifle the reporting of sexual harassment. It is not enough to criminalize quid pro quo harassment as it is not a guarantee that all of its victims will come out.

5.2. Socio Cultural Barriers The findings indicated that some of the barriers to the reporting of sexual harassment are related to the social and cultural norms that are attached to sexuality. The traditions and beliefs about male and female sexuality can potentially stop victims from reporting complaints as they are afraid of the victimhood label. Participants in this study noted that the fear, shame and blame that might come with being identified as a victim of sexual harassment impeded students from reporting their experiences. One female student noted that it was better not to report sexual harassment because reporting could damage one's marriage prospects and that the victim could be abandoned by friends. The participant noted;

The victim gets ashamed and can lose confidence amongst her friends. It brings a bad image to ones' self because they see you in a different way. Even when you have someone who wants to marry you, they would change their mind.

Another female student noted that the mark of being a victim of sexual harassment could damage one's reputation. She opined thus;

Some of the girls who experience sexual harassment blame themselves for what has happened. They think, I have gone to a lecturer's office and he has done this to me but I want to keep my reputation so I should keep quite.

Another female student shared a vivid experience in which she had been actively involved. She opined;

We thought about reporting but she told me that now that the lecturer was no longer disturbing her, she did not have to report the case. At our own level, that is the best thing that we could do, it was a way of protecting herself. Actually she was in total fear. She did not want other students to know about this. That is the major issue on ground, most people fear to be known that so and so has issues with a lecturer.

The fear of the victimhood label may be related to the stigma that is associated with being a victim of sexual abuse as implied by a university administrator who participated in this study. When asked why so few victims stepped forward, he noted; 
It is a stigmatizing kind of thing. Studies show that people who have been raped or defiled have a higher tendency of that happening to them again. This is because sexual matters tend to be very private for many people and so people do not want to be associated with something so shameful. It touches the core of the person, people do not want to be exposed.

A female member of faculty noted the difficulties that victims may face recounting their sexual harassment experiences;

It is hard because the girls do not want to talk. Evidence is a big issue and they want the girls to recount their experiences, even people start talking. It is a shameful act where people will whisper.

The participant above makes reference to the discomfort that victims of sexual harassment may face in recounting their experiences. Victims may be afraid of being evaluated negatively especially by their peers and thus prefer not to report sexual harassment.

5.3. Financial Inadequacies: The findings indicated that victims may not reports sexual harassment because they perceive themselves to be in a weaker financial position than the perpetrators. A female student alluded to the difficulty of reporting a faculty member when she could not even afford legal fees. She commented thus;
It is scary. You know, you are some poor student and you are going to report this rich guy, a lecturer. You think where will I get the money for a lawyer and will not the university throw me out?

It was also noted that perpetrators bribed victims to the point where victims decided not to report the harassment. Asked why victims of sexual harassment seldom reported, a female student suggested that sometimes the perpetrators bought off the victims. She commented thus;
There are also some cases where they are bribed, a lecturer finds out that you are going to report him, he bribes you, he can tell you I can do everything for you. I have heard about that case in my college. She had all the evidence but he bribed her with money and this girl kept quiet.

Owing to what the participants above say, it is likely that victims may not report sexual harassment because of their weak financial position and the perception that the perpetrators are financially better placed than they are.

\section{DISCUSSION OF FINDINGS}

The findings of this study suggest that female students who try to pursue justice face multifaceted institutional barriers both from the people who should help them to get justice and from the grievance handling mechanism through which sexual harassment complaints should be handled. They are also held back by society's perceptions regarding gender and sexuality. The findings point to the complexities regarding evidentiary standards in the handling of sexual harassment complaints. The burden of proof has long been a problem in the handling of sexual harassment complaints [26]. The bar is sometimes set to high which discourages victims from stepping forward (Ibid)[26]. It ought to be noted that at the time data for this study was collected, the university's grievance handling mechanism did not have a clear standard of proof which could have further complicated the handling of sexual harassment complaints. Without a clear evidentiary standard, complaint handlers could have had to second guess how to deal with complaints.

The findings also suggested that the perceived neutrality of the complaint handlers was low. This was largely driven by their inaction which could have led to a loss of trust in the grievance handling mechanism. It ought to be noted that each academic unit was mandated to set up its own unit sexual harassment committee which was automatically chaired by the head of the unit. This model of handling sexual harassment complaints is problematic as it is based on the assumption that the power inequalities that are inherent in such environments will not affect how the complaints are handled [3]. It is perhaps these power inequalities between students and faculty that may partly explain the inaction of complaint handlers.

Entrusting faculty to deal with the sexual harassment complaints that may implicate their colleagues and members of their professional network is a sure way to deny justice to victims who have been abused by those who hold power in universities Feminist scholars have argued that such scenarios mask how patriarchy can be embedded in laws and policies [27]. It is also important to note that the decentralization of handling sexual harassment complaints diminishes accountability for how 
complaints are handled [3]. The power differentials between faculty and students may explain why the threat of punishment is always alive for students who reject or report the sexual advances of their instructors. The power held by members of faculty is coercive as they can retaliate against students who do not do as they please [28]. The findings of this study validate this argument.

These findings also support the notion that victims of sexual harassment may feel that their sexual behavior is under scrutiny during the handling of sexual harassment complaints [25]. This in itself can stop victims of sexual harassment from stepping forward. And as the findings suggested, reporting comes with a label of being a victim of sexual abuse which some victims might not want to be associated with.

The fear of the victim label has been attested to by scholars [29, 30, 31]. This is not new as other studies have suggested that people often evaluate victims who report sexual harassment harshly. It has also been argued that women who report sexual harassment are considered to be problematic, over reacting and troublemakers [11] which might lend credence to the notion that in some circumstances reporting sexual harassment may make things worse for the victim. [11,32].When a victim of sexual violence anticipates disapproval from others, they will most likely ensure that they remain invisible which might decrease their chances of reporting harassment [33].

It is important to deconstruct the shame that is felt by victims of sexual harassment and how this may hamper them from reporting sexual harassment. The shame that comes with being a victim of sexual violence is socially constructed around narratives regarding gender and sexuality [34]. Victims of sexual crimes are often constructed as dirty or damaged and thus unfit for marriage $[34,33]$. Being a victim of sexual harassment is a threat to one's gendered self and would rather be kept in the closet than to report it and suffer the consequences of being labeled a victim. These findings indicate that victims of sexual harassment do face multiple victimizations; first by the perpetrators, secondly by the justice system that lets them down and by the society that blames them for their predicament [35].

The findings of this study give credence to the notion that sexual harassment is a complex problem that defies simple solutions[36]. The elusive and pervasive nature of quid pro quo harassment goes to show how complex it can be and thus the need to treat is as such; a complex problem. While anti sexual harassment policies often make it clear that submission to quid pro quo harassment does not erase the wrong in it [37]; the complexity of the problem is that those who submit to it will most likely not report it thus making it invisible. When quid pro quo goes unpunished, it has repercussions for women as a group and specifically women in academia as it produces 'negative female learner identities' [38] where the achievements of women in higher education are attributed to sexual favors.

\section{LiMitations OF THE STUDY}

The study specifically focused on why female undergraduate students do not or may not report faculty perpetrated sexual harassment, these results cannot therefore be generalized to other groups within the university.

\section{CONCLuSiOnS}

The findings of this study have offered insights into why victims of sexual harassment may not take advantage of the opportunities offered by universities to report sexual harassment. University grievance handling mechanisms will remain unused unless universities minimize the harms that may come with using them. Sexual harassment cannot be tackled without the cooperation of the victims and victims will not come forward if measures are not taken to minimize harm to them. This points to the importance of paying attention to the personal, social and institutional barriers that hamper victims from reporting complaints.

\section{RECOMMENDATIONS}

Basing on the findings of this study, some recommendations have been made. Accused perpetrators should not grade victims so as to minimize the possibility of retaliation and the sanctions for retaliatory behavior should be severe enough to discourage the practice.

It is also important to educate the university community about the wrongs of quid pro quo harassment and to put in place measures that ensure that it will be reported, for example by allowing third parties to report complaints.

University managers ought to ensure that complaint handlers are well positioned to fairly handle sexual harassment complaints and that they employ effective investigative strategies while doing so. This may help victims to build trust in the grievance handling mechanisms thus encouraging them to report the vice. 


\section{REFERENCES}

[1] Foster, P. J., \& Fullagar, C. J. (2018). Why don't we report sexual harassment? An application of the theory of planned behavior. Basic and Applied Social Psychology, 40(3), 148-160.

[2] Hill, C., \& Silva, E. (2005). Drawing the line: Sexual harassment on campus. American Association of University Women Educational Foundation, 1111 Sixteenth St. NW, Washington, DC 20036.

[3] Kihnley, J. (2000). Unraveling the ivory fabric: Institutional obstacles to the handling of sexual harassment complaints. Law \& Social Inquiry, 25(1), 69-90.

[4] Thomas*, A. M. (2004). Politics, policies and practice: assessing the impact of sexual harassment policies in UK universities. British journal of sociology of education, 25(2), 143-160.

[5] Cantor, D., Fisher, B., Chibnall, S. H., Townsend, R., Lee, H., Thomas, G.Westat, I. (2015). Report on the AAU campus climate survey on sexual assault and sexual misconduct: Association of American Universities Washington, DC.

[6] Lawton, A. (2006). Between Scylla and Charybdis: The Perils of Reporting Sexual Harassment. U. Pa. J. Lab. \& Emp. L., 9, 603.

[7] Alayan, S., \& Yair, G. (2010). The cultural inertia of the habitus: gendered narrations of agency amongst educated female Palestinians in Israel. British Educational Research Journal, 36(5), 831-850.

[8] Fisher, B. S., Cullen, F. T., \& Turner, M. G. (2000). The sexual victimization of college women: Research report. Department of Justice, Washington DC. National Institute of Justice.

[9] Rozee, P. D., \& Koss, M. P. (2001). Rape: A century of resistance. Psychology of sexual harassment. Organization Science, 24(2), 614-628.

[10] Orchowski, L. M., Meyer, D. H., \& Gidycz, C. A. (2009). College women's likelihood to report unwanted sexual experiences to campus agencies: Trends and correlates. Journal of Aggression, Maltreatment \& Trauma, 18(8), 839-858.

[11] Hebert, L. C. (2007). Why Don't Reasonable Women Complain about Sexual Harassment. Ind. LJ, 82, 711.

[12] Hertzog, J. L., Wright, D., \& Beat, D. (2008). There'sa policy for that: A comparison of the organizational culture of workplaces reporting incidents of sexual harassment. Behavior and Social Issues, 17(2), 169-181.

[13] Clancy, K. B., Cortina, L. M., \& Kirkland, A. R. (2020). Opinion: Use science to stop sexual harassment in higher education. Proceedings of the National Academy of Sciences, 117(37), 22614-22618.

[14] Gillander Gådin, K., \& Stein, N. (2019). Do schools normalise sexual harassment? An analysis of a legal case regarding sexual harassment in a Swedish high school. Gender and Education, 31(7), 920-937.

[15] Vijayasiri, G. (2008). Reporting sexual harassment: The importance of organizational culture and trust. Gender Issues, 25(1), 43-61.

[16] Marshall, A. M. (2005). Idle rights: Employees' rights consciousness and the construction of sexual harassment policies. Law \& Society Review, 39(1), 83-124.

[17] Pinchevsky, G. M., Magnuson, A. B., Augustyn, M. B., \& Rennison, C. M. (2019). Sexual victimization and sexual harassment among college students: A comparative analysis. Journal of Family Violence, 1-16.

[18] Cortina, L. M., \& Wasti, S. A. (2005). Profiles in coping: Responses to sexual harassment across persons, organizations, and cultures. Journal of Applied Psychology, 90(1), 182.

[19] Cochran, C. C., Frazier, P. A., \& Olson, A. M. (1997). Predictors of responses to unwanted sexual attention. Psychology of Women Quarterly, 21(2), 207-226.

[20] Wendell, S. (1990). 'Oppression and Victimization; Choice and Responsibility.' Hypatia 5(3):15-46.

[21] Zinzow, H. M., \& Thompson, M. (2011). Barriers to reporting sexual victimization: Prevalence and correlates among undergraduate women. Journal of Aggression, Maltreatment \& Trauma, 20(7), 711-725.

[22] Van Bruggen, L. K., Runtz, M. G., \& Kadlec, H. (2006). Sexual revictimization: The role of sexual self-esteem and dysfunctional sexual behaviors. Child maltreatment, 11(2), 131-145.

[23] Carter, P., \& Jeffs, T. (1995). Very Private Affair: Sexual Exploitation in Higher Education: Education Now Publishing Co-operative.

[24] Lunenburg, F. C. (2010). Sexual harassment: An abuse of power. International Journal of Management, Business, and Administration, 13(1), 1-7.

[25] Feldman-Summers, S. (2000). Analyzing anti-harassment policies and complaint procedures: Do they encourage victims to come forward. Lab. Law., 16, 307. 
[26] Loschiavo, C., \& Waller, J. L. (2015). The preponderance of evidence standard: Use in higher education campus conduct processes. Association of Student Conduct Administration, 1-6.

[27] Marshall, C., Dalyot, K., \& Galloway, S. (2014). Sexual harassment in higher education: Re-framing the puzzle of its persistence. Journal of Policy Practice, 13(4), 276-299.

[28] Townsend, B. K. (1995). Gender and Power in the Community College. New Directions for Community Colleges, Number 89. Jossey-Bass Publishers, 350 Sansome St., San Francisco, CA 94104-1342. Association of University Women Educational Foundation, 1111 Sixteenth St. NW

[29] Lindenberg,KE and Reese LA (1993). Implementing Sexual harassment policy. On Calling a Pig a Dog. Paper presented at the annual meeting of the American Society for Public Administration, San Francisco

[30] Gutek, B. A., \& Koss, M. P. (1993). Changed women and changed organizations: Consequences of and coping with sexual harassment. Journal of Vocational Behavior, 42(1), 28-48.

[31] Koss,M.P (1990). Changed Lives: The Psychological Impact of Sexual Harassment.. 73-92 In M. A Paludi (ed.) Ivory Tower: Sexual Harassment on Campus. Albany, NY.

[32] Welsh, S., \& Gruber, J. E. (1999). Not taking it any more: Women who report or file complaints of sexual harassment. Canadian Review of Sociology/Revue canadienne de sociologie, 36(4), 559-583.

[33] Feiring, C., \& Taska, L. S. (2005). The persistence of shame following sexual abuse: A longitudinal look at risk and recovery. Child maltreatment, 10(4), 337-349.

[34] Weiss, K. G. (2010). Too ashamed to report: Deconstructing the shame of sexual victimization. Feminist Criminology, 5(3), 286-310.

[35] Diekmann, K. A., Walker, S. D. S., Galinsky, A. D., \& Tenbrunsel, A. E. (2013). Double victimization in the workplace: Why observers condemn passive victims of sexual harassment. Organization Science, 24(2), 614-628.

[36] Dougherty, D. (2010). Wicked Problems Defy Simple Solutions: Why Sexual Harassment Policy Doesn't Work Marlo Goldstein Hode University of Missouri COMM 8410 December 13, 2010.

[37] Baker, C. N. (1995). Sexual Extortion: Criminalizing Quid Pro Quo Sexual Harassment. Law \&Ineq., 13, 213.

[38] Morley, L. (2011). Sex, grades and power in higher education in Ghana and Tanzania. Cambridge Journal of Education, 41(1), 101-115.education campus conduct processes. Association of Student Conduct Administration, 1-6.

AUTHOR'S BIOGRAPHY

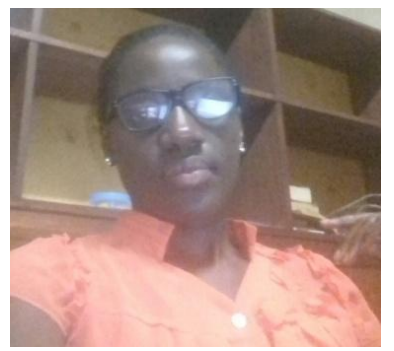

Agnes Namaganda, is Doctoral Candidate of Higher Educational Management at Makerere University. She holds a Master of Arts in Educational Policy and Planning. Her research interests include policy, gender and sexual violence.

Citation: Agnes Namaganda, et.al. "Examining the Barriers to Reporting Sexual Harassment in Universities" International Journal of Humanities Social Sciences and Education (IJHSSE), vol 8, no. 1, 2021, pp. 6-15. doi. https://doi.org/10.20431/2349-0381.0801002.

Copyright: (C) 2021 Authors. This is an open-access article distributed under the terms of the Creative Commons Attribution License, which permits unrestricted use, distribution, and reproduction in any medium, provided the original author and source are credited. 